Kocatepe Vet J (2013) 6(1): 11-17

DOI: $10.5578 / \mathrm{kvj} .5476$

Kabul Tarihi : 14.05 .2013

RESEARCH ARTICLE

ARAŞTIRMA MAKALESI

Key Words

Body and Udder Measurements Canonical Correlations Holstein Cows

Anahtar Kelimeler Vücut ve Meme Ölçüleri Kanonik Korelasyon Holştayn İnek

${ }^{1}$ Adnan Menderes University Bozdoğan Vocational School Animal Breeding and Health Program Aydın -Turkey

2 Dicle University Faculty of Agriculture Department of Zootechny Diyarbakır - Turkey

* Corresponding author Email: alicdeniz@gmail.com Telefon: +90 (256) 4143738

\section{Determination of Relationship between Some Udder and Body Traits of Holstein Cows by Canonical Correlation Analysis}

\author{
Deniz ALIÇ URAL ${ }^{1} *$ İlkay BARITÇI ${ }^{2}$
}

\section{S U M M A R Y}

The purpose of the research was to obtain the relationship between some udder and body traits. In an attempt to perform the study, canonical correlations among height at withers (HW), shinbone perimeter (SP), body length (BL), chest girth (CG), stature (S), rump width (RW), rear udder height (RUH), right fore udder teat perimeter (RFUTP), right rear udder teat perimeter (RRUTP), left fore udder teat perimeter (LFUTP), left rear udder teat perimeter (LRUTP), fore udder teat length (FUTL), and rear udder teat length (RUTL) in 50 head Holstein cows that were raised at a dairy farm in Bozdogan province in Aydin county, were estimated. Six body traits constituted the $\mathrm{X}$ variable set while seven udder traits constituted the $\mathrm{Y}$ variable set. As a result, the correlation between the first canonical variable pair was found $0.62(\mathrm{P}>0.05)$. The contribution occurrences of canonical variables of $\mathrm{HW}$ and $\mathrm{BL}$ from body traits and LRUTP and RRUTP from udder traits were found the highest than others. According to these results, the degrees of explanation (redundancy) of change on each other of the two variable sets $\left(\mathrm{U}_{1}\right.$ and $\left.\mathrm{V}_{1}\right)$ were found $6.2 \%$ and $2.1 \%$, respectively.

\section{Kanonik Korelasyon Analizi ile Holştayn İneklerin Bazı Meme ve Vücut Özellikleri Arasındaki İlişkinin Saptanması}

\section{ÖZET}

$\mathrm{Bu}$ çalışmanın amacı, bazı meme özellikleri ile vücut özellikleri arasındaki ilişkinin ele alnımasıdır. Bu amaçla, Aydın ilinin Bozdoğan ilçesinde bulunan bir süt sığırcıllı̆̆ işletmesinde yetiştirilen 50 baş Holştayn inekte cidago yüksekliği (CY), incik çevresi (IÇ), vücut uzunluğu (VU), göğüs çevresi (GÇ), sağr1 yüksekliği (SY), sağrı genişliği (SG), arka meme yüksekliği (AMY), sağ ön meme baş1 çevresi (SÖMBÇ), sağ arka meme başı çevresi (SAMBÇ), sol ön meme baş1 çevresi (SLÖMBÇ), sol arka meme başı çevresi (SLAMBÇ), ön meme baş1 uzunluğu (ÖMBU) ve arka meme başı uzunluğu (AMBU) arasındaki kanonik korelasyonlar tahmin edilmiştir. 7 meme özelliği Y değişken seti olarak alınırken, 6 vücut özelliği de $\mathrm{X}$ değişken seti olarak alınmıştır. Sonuçta, birinci kanonik değișken çifti arasındaki korelasyon 0.62 olarak bulunmuștur (P> 0.05). Vücut ölçülerinden CY ile VU, meme SLAMBÇ ile SAMBÇ’ye ait kanonik değişkenlerin yaptığı katk1 diğerlerine göre daha yüksek bulunmuştur. Elde edilen sonuçlara gore, iki değişken setinin $\left(\mathrm{U}_{1}\right.$ ve $\left.\mathrm{V}_{1}\right)$ birbiri üzerindeki değişimi açıklama derecesi (gereksizlik indeksi) sırasıyla \% 6.2 ile \% 2.1 bulunmuştur. 


\section{INTRODUCTION}

Several body measurements are important selection criteria. Several management practices involving selection are used to evaluate animal body condition (Ulutas et al 2001, Tolenkhomba et al 2012). Certain body measurements carry out importance in particular beef and dairy cattle selection and breeding programmes. Measurements such as rump height or wither height may be used for monitoring skeletal development (Van MarleKöster et al 2000).

Significant studies relevant to body and udder measurements in cattle have been investigated by many authors (Sieber et al 1988, Gilbert et al 1993, Seker et al 2000, Kul 2006, Coban et al 2009, Ozkaya and Bozkurt 2009, Dascălu et al 2012, Tolenkhomba et al 2012). The correlations among body measurements were found lower (Sieber et al 1988, Tolenkhomba et al 2012) and higher (Gilbert et al 1993, Ozkaya and Bozkurt 2009) by different authors. Relationships among body measurements and udder traits have been investigated by some researchers (Gengler et al 1997, Beretti et al 2010). The authors detected significant correlation between measurements.

Analysis of canonical correlation is widely used for the degree and direction of relationships among determining different body measurements of animals (Unalan and Cebeci 2004, Cankaya and Kayaalp 2007, Tolenkhomba et al 2012). In 1935, Canonical correlation analysis (CCA) was developed by Hotelling (Sharma 1996) a technique for defining the relationship among two variable sets by computing linear combinations that are supreme correlated. Besides, CCA has the ability to tackle with two variable sets synchronously and to produce both structural and spatial meanings (Bilgin et al 2003). The discrepancy is that in CCA both the estimator and criterion are composites while in multiple regression analysis only the estimator is a compound (Cankaya and Kayaalp 2007, Koskan et al 2011).

The aim of this study was to determine the relationship between some udder and body traits of Holstein cows by canonical correlation analysis.

\section{MATERIAL AND METHOD}

Data consisted of 6 body and 7 udder measurements on 50 head Holstein-Friesian cows were collected during 2011 to January 2012 from a dairy farm in Bozdogan county in Aydin, Turkey. All measurements were recorded as biweekly and were collected about some udder measurements [ rear udder height (RUH), right fore udder teat perimeter (RFUTP), right rear udder teat perimeter (RRUTP),left fore udder teat perimeter (LFUTP), left rear udder teat perimeter (LRUTP), fore udder teat length (FUTL), rear udder teat length (RUTL)] and body measurements [height at withers (HW), shinbone perimeter (SP), body length (BL), chest girth (CG), stature (S), rump width (RW)] by measurement cane and tape. Those measured sets of data were the main values of this study. In determination of relationship between those two sets of data was profited from Canonical Correlations (CCA). All the analysis were carried out using the SYSTAT package program in this study (SYSTAT 2013).

\section{Canonical correlation analysis (CCA)}

By CCA analysis, maximum correlations of linear functions of the set of chance variables were determined. The linear components of each variable were diminished to a solitary canonical variable. Consequently, the correlation of the canonical variables among two groups was determined. In a sense, random group of variables of each variable, the maximum correlation and linear unit variance constituents were attained. Thereafter the second canonical pair was detected. This was done so long as all probable pairs of variables were attained (Bilodeau and Brenner 1999). This procedure would sustain till an equal number of pair of canonical variables of random variable of the group is obtained (Dogan et al 2012).

Behalf of the correlation between two variables, a set of linear combine of the lowest variables could be examined with canonical correlation model. Because, high in number of correlation coefficients were troublesome to explain separately. Canonical correlation analysis targets to decrease the number of correlation coefficients. For this reason, linear constituents of the first and second data sets are coupled to give the highest correlations. Data sets of the linear components are describes as (Cankaya et al 2010, Dogan et al 2012):

$$
\begin{aligned}
& U=a^{\prime} X^{(1)} \\
& V=b^{\prime} X^{(2)}
\end{aligned}
$$


and for the coefficient vectors a and b previously stated are obtained with:

$$
\begin{gathered}
\operatorname{Var}(U)=a^{\prime} \operatorname{Cov}\left(X^{(1)}\right) a=a^{\prime} \Sigma_{11} a \\
\operatorname{Var}(V)=b^{\prime} \operatorname{Cov}\left(X^{(2)}\right) b=b^{\prime} \Sigma_{22} b \\
\operatorname{Cov}(U, V)=a^{\prime} \operatorname{Cov}\left(X^{(1)}, X^{(2)}\right) b=a^{\prime} \Sigma_{12} b
\end{gathered}
$$

Thus, for vectors a and $b$, the highest correlation coefficient could be acquired with:

$$
\operatorname{Corr}(U, V)=\frac{a^{\prime} \sum_{12} b}{\sqrt{a^{\prime} \sum_{11} a} \sqrt{b^{\prime} \sum_{{ }_{22}} b}} \quad \mathrm{i}: 1,2, \ldots,
$$

\section{Interpretations of CCA and PCCA}

The null and alternative hypotheses for evaluating the statistical significance of the CCC are,

$$
\begin{gathered}
H_{0}=\rho_{1}=\rho_{2}=\ldots \ldots=\rho_{r}=0 \\
H_{1}=\rho_{i} \neq 0 \text { at least one i: } 1,2, \ldots ., \mathrm{r}
\end{gathered}
$$

The null and alternative hypotheses for evaluating the statistical significance of the PCCC are,

$$
\begin{gathered}
H_{0}=\rho_{1 . Y}=\rho_{2 . Y}=\ldots . .=\rho_{r}=0 \\
H_{1}=\rho_{\text {.i. } Y} \neq 0 \text { at least one i: } 1,2, \ldots \ldots, \mathrm{r}
\end{gathered}
$$

Bartlett test statistics for the statistical significance of $\rho^{2}$ is

$$
\chi^{2}=-[(n-1)-(p+r+1) / 2] \log _{e}\left(\coprod_{i=1}^{r}\left(1-p_{i}^{2}\right)\right.
$$

which is roughly dispensed as $\chi^{2}$ with $p r$ degrees of freedom. We reject $\mathrm{H}_{0}$ if $\chi^{2} \geq \chi_{\alpha}{ }^{2}$. Where, $\mathrm{n}$ : the number of cases, loge: the natural logarithm function, $\mathrm{p}$ : the number of variables in $\mathrm{X}$ set, $\mathrm{r}$ : the number of variables in $\mathrm{Z}$ set, $\rho_{l}^{2}$ : the eigenvalues $\Sigma^{-1}{ }_{11} \Sigma_{12} \sum^{-1}{ }_{22} \Sigma_{21}$ or the squared canonical correlations (Cankaya et al 2008).

Bartlett test statistics for the statistical significance of $\rho^{2}$ i. is

$$
\begin{gathered}
\chi^{2}= \\
=-[(n-q-1)-(p+r+1) / 2] \log _{e}\left(\coprod_{i=1}^{r}\left(1-p_{i . Y}^{2}\right)\right.
\end{gathered}
$$

where, q: the number of variables in Y set (Cankaya 2005).
The CCC and/or PCCC do not define the quantity of variance calculated for in one variable set by another variable set. Hence, it is proposed to account the redundancy measure for each canonical correlation to detect how much of the variance in one set of variables is calculated for by another set of variables redundancy measure can be formulated as below (Sharma, 1996):

$$
\begin{gathered}
R I_{U_{i} W_{i}}=O V\left(Z / W_{i}\right) \cdot \rho^{2}{ }_{u w} \\
O V\left(Z / W_{i}\right)=\frac{\sum_{i=1}^{p} L Z^{2} i j}{r}
\end{gathered}
$$

The first six characters were included in the first variable set (X: body traits), while latter seven characters were included in the second variable set (Y: udder traits).

\section{RESULTS}

In this study, descriptive statistics for body and udder traits were reported in Table 1.

Table 1. Descriptive Statistics for Body and Udder Traits $(\mathrm{N}=50)$

\begin{tabular}{llllll}
\hline Traits & Mean & $\begin{array}{l}\text { Standard } \\
\text { Deviation }\end{array}$ & Min & Max & C.V. \\
\hline HW & 127.90 & 9.992 & 116.000 & 149.000 & 0.078 \\
SP & 18.28 & 2.900 & 14.000 & 24.000 & 0.159 \\
BL & 120.30 & 6.463 & 110.000 & 135.000 & 0.054 \\
CG & 178.26 & 8.241 & 158.000 & 197.000 & 0.046 \\
S & 135.34 & 9.576 & 114.000 & 148.000 & 0.071 \\
RW & 39.46 & 3.052 & 32.000 & 45.000 & 0.077 \\
RUH & 25.58 & 4.743 & 15.000 & 32.000 & 0.185 \\
RFUTP & 8.36 & 1.363 & 4.500 & 11.000 & 0.163 \\
RRUTP & 8.27 & 1.161 & 5.000 & 11.000 & 0.140 \\
LFUTP & 8.55 & 0.950 & 7.000 & 12.000 & 0.111 \\
LRUTP & 8.47 & 1.229 & 4.000 & 11.500 & 0.145 \\
FUTL & 6.12 & 1.076 & 4.000 & 8.000 & 0.176 \\
RUTL & 5.29 & 1.217 & 2.000 & 8.000 & 0.230 \\
\hline
\end{tabular}

HW: Height at withers, SP: Shinbone perimeter, BL: Body length, CG: Chest girth, S: Stature, RW: Rump width, RUH: Rear udder height, RFUTP: Right fore udder teat perimeter, RRUTP: Right rear udder teat perimeter, LFUTP: Left fore udder teat perimeter, LRUTP: Left rear udder teat perimeter, FUTL: Fore udder teat length, RUTL: Rear udder teat length

The correlations displaying the relationship between first variable set (height at withers, rump perimeter, body length, chest perimeter, stature, and chest width) were presented in Table 2.

The highest correlation was between HW and BL (0.395), while the lowest correlations were predicted in first variable set (Table 2 ). 
Table 2. The Correlations Between First Variable Set

\begin{tabular}{ccccccc}
\hline Body Traits & HW & SP & BL & CG & S & RW \\
\hline HW & 1.000 & & & & & \\
SP & 0.040 & 1.000 & & & & \\
BL & 0.395 & 0.123 & 1.000 & & & \\
CG & 0.352 & 0.036 & 0.147 & 1.000 & & \\
S & 0.266 & 0.094 & 0.133 & 0.134 & 1.000 & \\
RW & -0.053 & -0.026 & -0.033 & -0.019 & 0.101 & 1.000 \\
\hline
\end{tabular}

HW: Height at withers, SP: Shinbone perimeter, BL: Body length, CG:

Chest girth, S: Stature, RW: Rump width.
The correlations between second variable set (rear udder height, right fore udder teat perimeter, right rear udder teat perimeter, left fore udder teat perimeter, left rear udder teat perimeter, fore udder teat length, rear udder teat length) were presented in Table 3. The highest correlation was among LRUTP and RRUTP (0.821), while the moderate correlations were generally found in second variable set (Table 3).

Table 3. The Correlations Between Second Variable Set

\begin{tabular}{lccccccc}
\hline & RUH & RFUTP & RRUTP & LFUTP & LRUTP & FUTL & RUTL \\
\hline RUH & 1.000 & & & & & & \\
RFUTP & 0.009 & 1.000 & & & & & \\
RRUTP & 0.336 & 0.534 & 1.000 & & & & \\
LFUTP & 0.122 & 0.465 & 0.601 & 1.000 & & & \\
LRUTP & 0.392 & 0.571 & 0.821 & 0.479 & 1.000 & & \\
FUTL & -0.136 & -0.091 & -0.037 & -0.148 & 0.085 & 1.000 & 1.000 \\
RUTL & 0.089 & 0.073 & 0.213 & -0.061 & 0.298 & 0.608 \\
\hline
\end{tabular}

RUH: Rear udder height, RFUTP: Right fore udder teat perimeter, RRUTP: Right rear udder teat perimeter, LFUTP: Left fore udder teat perimeter, LRUTP: Left rear udder teat perimeter, FUTL: Fore udder teat length, RUTL: Rear udder teat length

The correlations between two variable set were given in Table 4. In study, the first six characters were included in the first variable set $(X$ : body traits) and seven characters were included in the second variable set (Y: udder traits). Table 4 was shown that values of correlation were found low and negatively between traits. The highest correlations were predicted between RUH-HW (0.224) and RFUTP-BL (-0.264).

Table 4. The Correlations Between Two Variable Set

\begin{tabular}{lcccccc}
\hline & HW & SP & BL & CG & S & RW \\
\hline RUH & 0.244 & 0.089 & 0.243 & 0.128 & 0.189 & -0.063 \\
RFUTP & 0.014 & -0.154 & -0.264 & 0.111 & 0.024 & 0.043 \\
RRUTP & 0.007 & 0.018 & -0.028 & 0.138 & -0.018 & -0.144 \\
LFUTP & -0.051 & 0.063 & -0.023 & 0.004 & -0.175 & -0.126 \\
LRUTP & 0.112 & 0.050 & 0.043 & -0.001 & -0.027 & -0.196 \\
FUTL & -0.131 & 0.074 & -0.098 & -0.170 & -0.137 & -0.141 \\
RUTL & -0.016 & -0.185 & -0.015 & 0.049 & 0.002 & -0.180 \\
\hline
\end{tabular}

HW: Height at withers, SP: Shinbone perimeter, BL: Body length, CG: Chest girth, S: Stature, RW: Rump width, RUH: Rear udder height, RFUTP: Right fore udder teat perimeter, RRUTP: Right rear udder teat perimeter, LFUTP: Left fore udder teat perimeter, LRUTP: Left rear udder teat perimeter, FUTL: Fore udder teat length, RUTL: Rear udder teat length

The canonical coefficients and loadings were given in Table 5. The maximum correlation and linear unit variance constituents were predicted and the first canonical pair $\left(\mathrm{U}_{1}\right.$ and $\mathrm{V}_{1}$ ) is detected. The linear constituents of the first canonical data are describes as:

$$
\begin{aligned}
& \mathrm{U}_{1}=0.154(\mathrm{HW})+0.553(\mathrm{SP})+0.396(\mathrm{BL})-0.602 \\
& (\mathrm{CG})-0.383(\mathrm{~S})-0,266(\mathrm{RW}) \\
& \mathrm{V}_{1}=0.108(\mathrm{RUH})+0.921(\mathrm{RFUTP})+0.735 \\
& (\mathrm{RRUTP})-0.504(\mathrm{LFUTP})-1.253(\mathrm{LRUTP})-0.449 \\
& (\text { FUTL })+0.534 \text { (RUTL) }
\end{aligned}
$$

Table 5. CC and Loadings

\begin{tabular}{lcc}
\hline & CC & CL \\
\hline HW & 0.154 & 0.033 \\
SP & 0.553 & 0.557 \\
BL & 0.396 & 0.394 \\
CG & -0.602 & -0.516 \\
S & -0.383 & -0.345 \\
RW & -0.266 & -0.329 \\
RUH & 0.108 & -0.080 \\
RFUTP & 0.921 & 0.444 \\
RRUTP & 0.735 & 0.062 \\
LFUTP & -0.504 & -0.187 \\
LRUTP & -1.253 & -0.202 \\
FUTL & -0.449 & -0.282 \\
RUTL & 0.534 & 0.151 \\
\hline
\end{tabular}

CC: Canonical coefficients, CL: Canonical loadings, HW: Height at withers, SP: Shinbone perimeter, BL: Body length, CG: Chest girth, S: Stature, RW: Rump width, RUH: Rear udder height, RFUTP: Right fore udder teat perimeter, RRUTP: Right rear udder teat perimeter, LFUTP: Left fore udder teat perimeter, LRUTP: Left rear udder teat perimeter, FUTL: Fore udder teat length, RUTL: Rear udder teat length

The contribution occurrences of canonical variables of RP and BL from body measurements and RFUTP and RRUTP from udder measurements were found the highest than others when the 
coefficients of canonical pair $\mathrm{U}_{1}$ and $\mathrm{V}_{1}$ were analyzed (Table 5).

The redundancy measure for each canonical correlation to detect how much of the variance in one set of variables was calculated for by another set of variables redundancy measure were realized and the results were given Table 6 . The separate six CCCs (canonical correlation coefficients) were calculated for determining of relationships between body and udder traits. We found that estimated CCC among $\mathrm{U}_{1}$ and $\mathrm{V}_{1}(0.620)$ were non-significant. According to these results, the degrees of explanation (redundancy) of change on each other of the two variable sets $\left(\mathrm{U}_{1}\right.$ and $\left.\mathrm{V}_{1}\right)$ were found $6.2 \%$ and $2.1 \%$, respectively (Table 6 ).

Table 6. The Results of CCA

\begin{tabular}{|c|c|c|c|c|c|c|}
\hline Canonical variate pair & Canonical R & $\mathrm{CCR}^{2}$ & $\begin{array}{l}\text { I. Set Canonical } \\
\text { Redundancy }\end{array}$ & $\begin{array}{l}\text { II. Set Canonical } \\
\text { Redundancy }\end{array}$ & Degree of freedom & Probability \\
\hline $\mathbf{U}_{1} \mathbf{V}_{1}$ & 0.620 & 38.065 & 0.062 & 0.021 & 42 & 0.752 \\
\hline $\mathbf{U}_{2} \mathbf{V}_{2}$ & 0.415 & 17.697 & 0.044 & 0.022 & 30 & 0.978 \\
\hline $\mathbf{U}_{3} \mathbf{V}_{3}$ & 0.326 & 9.739 & 0.015 & 0.012 & 20 & 0.975 \\
\hline $\mathbf{U}_{4} \mathbf{V}_{5}$ & 0.268 & 5.017 & 0.010 & 0.006 & 12 & 0.957 \\
\hline $\mathbf{U}_{5} \mathbf{V}_{5}$ & 0.184 & 1.893 & 0.005 & 0.011 & 6 & 0.887 \\
\hline $\mathbf{U}_{6} \mathbf{V}_{6}$ & 0.103 & 0.446 & 0.002 & 0.002 & 2 & 0.848 \\
\hline
\end{tabular}

Canonical R: Canonical correlation coefficients, CCA: Canonical correlation analysis, $\mathrm{U}_{\mathrm{i}} \mathrm{V}_{\mathrm{i}}$ : The canonical variable pairs for the variable sets.

\section{DISCUSSION}

The mean value of HW from body traits was determined as $127.9 \pm 9.92 \mathrm{~cm}$. This result was found lower than findings of some authors (Sieber et al 1988, Ozkaya and Bozkurt 2009, Beretti et al 2010) and was found higher in contrast to previous studies (Gilbert et al 1993, Tolenkhomba et al 2012). The mean values of SP $(18.2 \pm 2.90 \mathrm{~cm})$ were found similar to findings of Dascălu et al (2012). The mean value of $\mathrm{BL}(120.3 \pm 6.46 \mathrm{~cm})$ was found higher than findings of some researchers (Gilbert et al 1993, Tolenkhomba et al 2012) and lower than others (Sieber et al 1988, Ozkaya and Bozkurt 2009). The mean value of CG $(178.2 \pm 8.24 \mathrm{~cm})$ was found lower than findings of some authors (Sieber et al 1988, Ozkaya and Bozkurt 2009, Dascălu et al 2012) and was found higher than one author (Tolenkhomba et al 2012). The mean value of S $(135.3 \pm 9.57 \mathrm{~cm})$ was found higher than findings of some researchers (Gilbert et al 1993, Ozkaya and Bozkurt 2009) and lower than one author (Beretti et al 2010). The mean value of RW from body measurements $(39.4 \pm 3.05 \mathrm{~cm})$ was found lower than findings of certain authors (Sieber et al 1988, Gilbert et al 1993, Ozkaya and Bozkurt 2009, Beretti et al 2010, Dascălu et al 2012).

The means value of RUH $(25.5 \pm 4.74 \mathrm{~cm})$ was determined lower than findings of one researcher (Coban et al 2009, Beretti et al 2010, Colceri 2011). The mean values of RFUTP, RRUTP, LFYTP and LRUTP $(8.36 \pm 1.36 \mathrm{~cm}, 8.27 \pm 1.16$ $\mathrm{cm}, 8.52 \pm 0.95 \mathrm{~cm}, 8.47 \pm 1.22 \mathrm{~cm}$, respectively) were found higher than findings of one researcher (Alic Ural 2013). The mean values of FUTL (6.12 \pm $1.076 \mathrm{~cm}$ ) was found lower than findings of some authors (Seker et al 2000), higher than findings of some researchers (Kul 2006, Coban et al 2009) and similar to findings of some researchers (Beretti et al 2010, Colceri 2011, Alic Ural 2013). The mean values of RUTL $(5.29 \pm 1.21 \mathrm{~cm})$ was found higher than findings of some researchers (Kul 2006), lower than findings of one researcher (Seker et al 2000, Beretti et al 2010) and similar to findings of some researchers (Coban et al 2009, Colceri 2011, Alic Ural 2013).

The analysis of canonical correlation gives to us the chance to predict the correlation among two sets of variables containing more than one trait in each at the same breath (Akbas and Takma 2005). In this study, canonical correlations were used to explain of interrelationships between two variable sets. The highest correlation was between HW and BL (0.395) in first variable set and among LRUTP and RRUTP (0.821) in second variable set. The canonical correlation among HW and CP (0.35) in first variable set was found same as findings of Tolenkhomba et al (2012). A similar situation was determined by Beretti et al (2010) for correlations among teat length in second set correlations.

We found prediction between two variable sets and the highest correlations were estimated among RUH-HW (0.224) and RFUTP-BL (-0.264). 
Beretti et al (2010) was found the highest correlations for RUH and S (0.437).

The highest $\mathrm{CC}$ was obtained from RFUTP $(92.1 \%)$. Whereas, the highest CC was found CG $(62.0 \%)$ (Ozkaya and Bozkurt 2009). The highest canonic loading was found as 0.557 (S) for first variable set. Although the highest canonic loading 0.444 (RFUTP), this result was accepted nonsignificant for this loading smaller than 0.50 . Tolenkhomba et al (2012) was found the highest loading for BL.

The canonical correlations between the first and second pair of canonical variate were found to be non-significant $(\mathrm{P}>0.01)$ from the likelihood ratio test. CCC was estimated that about 0.620 among $\mathrm{U}_{1}$ and $\mathrm{V}_{1}$.

\section{CONCLUSION}

Due to the fact that long steps necessary, difficulties for the interpretation of the results obtained and necessary calculation, researchers prefer simple methods rather than canonic correlation analysis. Albeit the importance of the latter analyze technique could not be ignored due to its emphasizing efficacy for revealing the structure of the relationship among two sets of variables without disrupting and providing more information than simple methods. Especially in terms of animal breeding studies early detected traits and later detected traits within economical significance must be provided without disturbing the integrity of the work, thus revealing selection researches is needed (Cankaya 2005, Cankaya et al 2009, Keskin et al 2005, Koskan et al 2011).

In the present study, the degree of relationship between udder and body traits was calculated and variances influencing on commenting were explained. According to present study, if the body traits at udder traits were used as early selection criteria in Holstein cows, studies on determination of relationship between udder traits and another body traits that are thought to be related, will continue in next.

\section{REFERENCES}

Akbaş Y, Takma C 2005. Canonical correlation analysis for studying the relationship between egg production traits and body weight, egg weight and age at sexual maturity in layers. Czech Journal of Animal Science, 50(4): 163-168.

Alic Ural D 2013. The relationships among some udder traits and somatic cell count in HolsteinFriesian cows. Kafkas Universitesi Veteriner Fakultesi Dergisi, (in press).

Beretti V, Simonazzi D, Paini V, , Superchi P, Sabbioni A 2010. Body measures in Reggiana cattle and their correlations with morphologic evaluations. Ann. Fac. Medic. Vet. di Parma, 91-102, http://www.unipr.it/arpa/facvet/ annali/2010/beretti.pdf, Accessed: March 2013.

Bilgin OC, Emsen E, Davis ME 2003. An application of canonical correlation analysis to relationships between the head and scrotum measurements in Awassi fat tailed lambs. Journal Animal and Veterinary Advances, 2 (6): 343-349.

Bilodeau M, Brenner D 1999. Theory of multivariate statistics. Springer, New York.

Cankaya S 2005. Kanonik korelasyon analizi ve hayvancilikta kullanımı. Cukurova Universitesi Fen Bilimleri Enstitusu Doktora Tezi, p. 145, Adana.

Cankaya S, Kayaalp. GT 2007. Estimation of relationship between live weights and some body measurements in German FarmxHair crossbred by canonical correlation analysis. Journal of Animal Production, 48:27-32.

Cankaya S, Ocak N, Sungu M 2008. Canonical correlation analysis for estimation of relationships between sexual maturity and egg production traits upon availability of nutrients in pullets. Asian-Australasian Journal of Animal Sciences, 21: 1576-1584.

Cankaya S, Balkaya A, Karaagac O 2010. Canonical correlation analysis for the determination of relationships between plant characters and yield components in red pepper [Capsicum annuum L. var. conoides (Mill.) Irish] genotypes. Spanish Journal of Agricultural Research, 8(1): 67-73.

Coban O, Sabuncuoglu N, Tuzemen N 2009. A study on relationships between somatic cell count (scc) and some uddertraits in dairy cows. Journal of Animal and Veterinary Advances, 8(1): 134-138.

Colceri D 2011. Influence of some genetic and environmental factors on udder milk-producing ability in Romanian Black and White. http://balnimalcon.nku.edu.tr/romanya/5/5.11.doc, Accessed: March 2013. 
Dascălu DL, Creangă Şt, Bugeac T, Borş I, Ruginosu E 2012. Observations on the morphoproductive characteristics of a nucleus of cattle, Grey Steppe breed. Lucrări Ştiințifice - Seria Zootehnie, 58: 166-171.

Dogan Z, Orhan H, Kaya L, Öztürk I, Yurtseven S 2012. Determination of relationship between nutrient and milk yield components of German Fawn $\times$ Hair crossbred by canonical correlation analysis. African Journal of Agricultural Research, 7(6): 964-969.

Gengler N, Wiggans GR, Wright JR, Norman HD, Wolfe CW 1997. Estimation of (co)variance components for Jersey type traits using a repeatability model. Journal of Dairy Science, 80:1801-1806.

Keskin S, Kor A, Baspinar E 2005. Akkeci oglaklarinda kesim oncesi ve kesim sonrasi olculen bazi ozellikler arasindaki iliski yapisinin kanonik korelasyon analizi ile irdelenmesi. Tarim Bilimleri Dergisi, 11(2):154-159.

Koskan O, Onder EG, Sen N 2011. Degisken Setleri Arasi Iliskinin Tahmini Icin Kanonik Korelasyon Analizinin Kullanimi. Igdir Universitesi Fen Bilimleri Enstitusu Dergisi, 1(2): 117-123.

Kul E 2006. Jersey sigirlarda bazi meme ozellikleri ile sut verimi ve sutteki somayik hucre sayisi arasindaki iliskiler. Ondokuz Mayis Universitesi Fen Bilimleri Enstitusu Yuksek Lisans Tezi, s.125, Samsun, http://www.belgeler.com/blg/ou5/jerseysiirlarinda-bazi-meme-zellikleri-ile-st-verimi-ve-stteki -somatik-hcre-sayisi-arasindaki-ilikiler- relationshipsbetween-some-udder-traits-and-milk- production-ormilk-somatic-cell-count-in-jersey-cows, Accessed: March 2013.

Gilbert RP, Bailey DR, Shannon NH, 1993. Body dimensions and carcass measurements of cattle selected for post-weaning gain fed two different diets. Journal of Animal Science, 71:1688-1698.

Ozkaya S, Bozkurt Y 2009. The accuracy of prediction of body weight from body measurements in beef cattle. Archiv Tierzucht, 52(4): 371-377.

Sieber M, Freeman AE, Kelley DH 1988. Relationships between body measurements, body weight, and productivity in Holstein dairy cows. Journal of Dairy Science, 71:3437-3445.

Sharma S 1996. Applied multivariate techniques: Canonical Correlation, 391-418. John Willey and Sons Inc., USA.

Seker I, Rişvanli A, Kul S, Bayraktar M, Kaygusuzoglu E 2000. Isvicre Esmeri ineklerde meme ozellikleri ve Sut Verimi ile Cmt skoru arasindaki iliskiler. Lalahan Hayvanciilik Arastitma Enstitusu Dergisi, 40(1): 29 - 38.

SYTAT 2013. Systat Software, Inc. $225 \mathrm{~W}$ Washington St., Suite 425 Chicago, IL 60606.

Tolenkhomba TC, Konsam DS, Shyamsana Singh N, Prava M, Damodor Singh Y, Ayub Ali M, Motina E, 2012. Factor analysis of body measurements of local cows of Manipur, India. International Multidisciplinary Research Journal, 2(2):77-82.

Ulutas Z, Saatci M, Ozluturk A 2001. Prediction of body weights from body measurements in East Anatolian Red calves. Journal of Agricultural Collage of Ataturk University, 32: 6165.

Unalan A, Cebeci Z 2004. Estimation of genetic parameters and correlations for the first three lactation milk yields in Holstein Friesian cattle by the REML method. Turkish Journal of Veterinary Animal Science, 28: 1043-1049.

Van Marle-Köster E, Mostert BE, Van der Westhuizen J 2000. Body measurements as selection criteria for growth in South African Hereford cattle Archiv Tierzucht, 43: 5-15. 